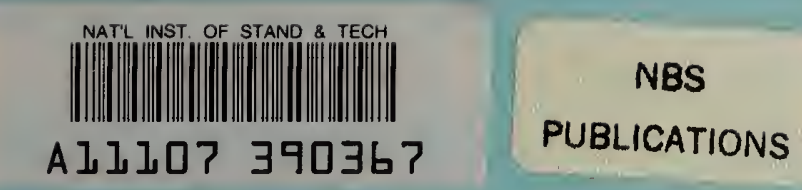

NBSIR 83-2770

\title{
Air Exchange Rate Measurements in the National Archives Building
}

Prepaced for and sponsored by:

Public Buildings Service

General Services Administration

7 th and D Streets, SW

Washington, DC 20407

and

National Archives and Records Service National Archives Building

Washington, DC 20408 



\section{AIR EXCHANGE RATE MEASUREMENTS IN THE NATIONAL ARCHIVES BUILDING}

Samuel Silberstein

Richard A. Grot

Douglas O. Pruitt

Philip Engers

Patrick J. Lane

Steven E. Schweinfurth

August 1983

Prepared for and sponsored by:

Public Buildings Service

General Services Administration

7th and D Streets, SW

Washington, DC 20407

and

National Archives and Records Service National Archives Building

Washington, DC 20408

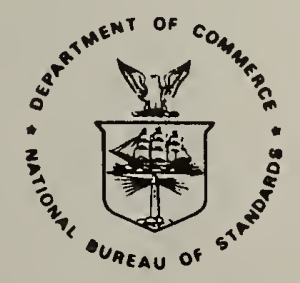

U.S. DEPARTMENT OF COMMERCE, Malcolm Baldrige, Secretary NATIONAL BUREAU OF STANDARDS, Ernest Ambler, Director 



\section{Abstract}

Air exchange measuremeris were carried out at the National Archives Building under various combinations of temperature and wind speed. The average air exchange rate under nornal operation of the heating, ventilating, and air-conditioning system (HVAC) was $0.9 \mathrm{~h}^{-1}$ for an average temperature difference of $11.3^{\circ} \mathrm{C}$ and an average wind speed of $2.7 \mathrm{~m} / \mathrm{s}$. This rate is approximately twice those for new General Services Administration (GSA) office cuildings. No clear dependence of air exchange rate on temperature differences up to $17^{\circ} \mathrm{C}$ or wind speeds up to $5 \mathrm{rr} / \mathrm{s}$ was found.

With outdoor air dampers closed and fans operating, the average air exchange rate was $1.2 \mathrm{~h}^{-1}$ for an average temperature difference of $8.20 \mathrm{C}$ and an average wind speed of $1.7 \mathrm{~m} / \mathrm{s}$.

A tes'c of interzone air movement showed that air migrates rapidly from non-stack to stack areas with fans operating normally.

The building could not be pressurized beyond an indooroutdoor pressure difference of $14 \mathrm{~Pa}$. At this pressure difference, the air exchange rate was $1.5 h^{-1}$. As in the case of normal operation of the HVAC system, this rate is also approximately twice those for new GSA office buildings. 



\section{INTRODU CTION}

The National Bureau of Standards (NBS) was asked by the General Services Adninistration (GSA) and the National Archives and Records Service (NARS) to measure air exchange rates of the National frchives Building under various conditions, including pressurization. This was done to aid in evaluating whether use of the current heating, ventilating, and air-conditionining (HVAC) system is consistent with preservation of archival records. The tests performed by NBS are as follows: 1) The air exchange rate of the building was measured under normal operation of the HVAC system. 2) The air exchange rate was measured with outdoor air dampers closed in order to determine how much air leakage was through dampers. 3) The air exchange rate was measured with dampers closed and fans off in order to determine how much the HVAC system contributes to air leakage. 4) Air leakage from the of $\mathrm{ice}$ and public areas to the stack areas was measured. 5) Fan pressurization measurements were performed in order to measure the intrinsic weather-independent envelope tightness of the building.

\section{METHODS}

The National Archives Building

The National Archives Building, located between Pennsylvania and Constitution Avenues, and between 7 th and 9 th Streets, in downtown Washington, is pictured in Fig. 1. Its volume is $306,253.5 \mathrm{~m} 3$, according to GSA. A schematic diagram of the building is shown in Fig. 2. The northern side of the building, bordering on Pennsylvania Avenue, is composed of ten stories of offices. Each of these stories is subdivided in the center of the building into from one to three floors of stacks, where records are stored. In addition, there are offices located on several of the stack floors. Nine air handling systems serve the building (other than the garage). Each system except for systems 2 and 4 is composed of two supply fans and a return fan; systems 2 and 4 are composed of one supply and return fan each. All fans in each system operate simultaneously. Fig. 2 shows the areas served by each system.

Installation of automated tracer gas equipment

One set of tubes and wires was connected from each airhandling system to a computer and electron-capture gas chromatography detector located in the basement. Each set of tubes and wires consists of $1 / 16$-inch inner diameter (id) plastic tubing for injecting tracer gas into the supply fans, $1 / 4-i n c h$ id plastic tubing for sampling return air, wiring conrected to a thermistor to measure return air temperature, and wiring connected to relays to determine whether fans were operating. In addition, a thermistor was placed outside the air intake of fan 1 
to measure outdoor temperature, and a weather station was

installed on the roof to measure wind speed and direction. All temperature and wind measurements were taken once a minute and the results averaged each hour. In all tests other than those for which fans were manually shut off, all fans operated continuously. Outdoor air dampers were automatically modul ated by the building HVAC system and no record was kept of their status.

\section{Automated tracer gas equipment used for all tests}

The automated tracer gas system developed at NBS and described elsewhere [1] was used to measure sulfur hexafluoride concentration and calculate hourly air exchange rates for each of the nine zones. The instrument was calibrated against samples containing known concentrations of sulfur hexafluoride. At 50 ninutes past the hour, the system injected sulfur hexafluoride tracer gas for up to ten minutes. The maximal flow rate per zone was $80 \mathrm{~L} / \mathrm{s}$. Concentrations at each location were measured by a gas chromatograph, electron capture detector at 10-minute intervals thereafter and the results recorded on a floppy disk. The last four concentrations were fit by regression analysis to an equation of the form:

$$
c=c_{0} e^{-I^{*} t}
$$

where

$$
\begin{aligned}
I & =\text { air exchange rate, } h-1 \\
t & =\text { time after injection, } h \\
C & =\text { concentration, ppb } \\
C_{0} & =\text { initial concentration, ppb }
\end{aligned}
$$

A weighted average of the nine air exchange rates was calculted and called the air exchange rate of the building. The weighting factors were closely related to the flow rates of the air handling systems. It would have been preferable to weight air exchange rates by relative zone volumes but these data were unavailable. Table 1 shows these flow rates and the weighting factors. Average indoor temperature was calculated from the nine return air temperatures. Because these temperatures were always very close to each other, they were not weighted. Regression aralysis of air exchange rate vs. indoor-outdoor temperature difference (always positive in these tests) was done essentially as described el sewhere [2]. Standard errors were also calculated as described in reference 2.

In the earlier tests conducted from March 24, 1983 through April 2, tracer gas was injected into each of the nine zones each hour and its concentration permitted to decay. It was found that gas was not always completely mixed within the first half hour. It was also found that tracer gas often migrated into zones 1-5. Therefore, for the later tests conducted from April 14 through 21, the system was programmed to inject gas once every three hours for the full 10-minute injection period into zones 6-9 
only. During the later tests, the tendency for gas to accumulate inzones $1-5$ was no I onger noted. Tracer gas was permitted to thoroughly mix during the first hour. During the third hour, concentrations were low. Consequently only data collected during the second hour were used. Fig. 3 shows that there is little difference between earlier and later data.

Test 1. Normal operation of the HVAC system

No modifications of the HVAC system were required for tests conducted under normal HVAC operation.

Test 2. Outdoor air dampers closed

To determine how much air leakage was through dampers, air exchange rates were measured between March 25 and 28 after the Archives maintenance staff shut all outdoor air dampers.

Test 3. Dampers closed and fans off

To determine how much the HVAC system contributes to air leakage, air exchange rates were measured during the evening of April 18 after the maintenance staff shut of the fans. Shutting of $f$ the fans automatically closed the outdoor-air dampers.

Test 4. Air leakage from the office and public areas to the stack areas

To determine whether air leaks into areas where archives are stored (stacks) from other areas (non-stack areas), gas was injected only into zones 1-5. Unlike during the earlier tests, it mixed evenly throughout the building. (These data were also used as normal fan-operation data.)

Test 5. Fan pressurization measurements

To measure the intrinsic weather-independent envelope tightness of the building, a fan pressurization test was conducted the evening of April 22. Sampling tubes leading from systems 8 and 9 were rerouted to sample air in stack areas $7 W-1$ and $14 \mathrm{~W}-1$, both served by air-handling system 6 , as seen in Fig. 1. Just prior to pressurizing the building, it was determined that tracer-gas concentrations in these two stack areas were nearly equal to that in return fan 6 , suggesting that tracer gas was uniformly distributed in that zone.

The maintenance staff shut off all the return air fans, closed the exhaust air dampers, and fully opened the supply air dampers (including dampers and fans serving the garage) prior to tracer gas injection. Tracer gas was manually injected for 30 minutes at a flow rate of $0.25 \mathrm{~L} / \mathrm{s}$ in order to maintain a high enough concentration for the high air exchange rates anticipated during the test. Differential pressure gauges were installed across the entrance doorways on Pennsylvania and Constitution Avenues. Since the concentrations in the two stack areas (and in fact in the remaining 7 air-handling systems) were all nearly 
constant during tracer gas injection at about $200 \mathrm{ppb}$, the air exchange rate was calculated by the equation:

$$
I=\mathrm{F} / \mathrm{C} \cdot \mathrm{V}
$$

where

$F=$ tracer gas flow rate, $\mathrm{m} 3 / \mathrm{h}$
$V=$ building volume, $\mathrm{m}$

Pressurization was maintained for three hours after injection was terminated. After injection was terminated, the air exchange rate was also calculated by the computer in the usual manner.

\section{RESULTS}

Test 1. Normal operation of the HVAC system

The results of air exchange rate measurements under normal HVAC-system operation are shown in Table 2. Fig. 3 shows air exchange rate measurements plotted against temperature difference with wind speeds indicated next to the points. Curves representing one standard error unit about the line are also shown. The average air exchange rate was $0.9 \pm 0.3 \mathrm{~h}^{-1}$, corresponding to an average temperature difference $(\Delta \mathrm{T})$ of $11.30 \mathrm{C}$ and an average wind speed of $2.7 \mathrm{~m} / \mathrm{s}$. During normal operation of the HVAC system, the average indoor temperature of the Archives Building remained nearly constant at $22.8 \pm 0.5^{\circ} \mathrm{C}$ (standard deviation or $s d$ ). The best-fit regression line is given by the equation:

$$
I=0.5+0.4(\Delta T)
$$

where

$$
\begin{aligned}
\Delta \mathrm{T} & =\mathrm{T}_{\text {in }}-\mathrm{T}_{\text {out }}, \mathrm{OC}^{\mathrm{C}} \\
\mathrm{T}_{\text {in }} & =\text { average indoor temperature, } \mathrm{OC} \\
\text { out } & =\text { outdoor temperature, }{ }^{\mathrm{C}}
\end{aligned}
$$

The correlation coefficient, $R^{2}$, is 0.23 , reflecting the 1 arge amount of data scatter. The uncertainty of the first coefficient, as measured by the standard error, is $97 \%$; the uncertainty of the second coefficient is $21 \%$. It can be seen in Fig. 3 that a linear relationship between $I$ and $\Delta T$ going through the origin cannot be excluded. Neither can the possibility that $\mathrm{I}$ is independent of $\Delta \mathrm{T}$ for $\Delta \mathrm{T}$ bel $\mathrm{OW} 17^{\circ} \mathrm{C}$ be excluded.

At constant $\Delta T$ (this can be visualized, for example, by going up any corridor $10 \mathrm{C}$ wide in Fig. 3), air exchange rate does not incrase with increasing wind speed; if anything, it decreases. In fact, there is no apparent relationship between air exchange rate and wind speeds of $0.6-5 \mathrm{~m} / \mathrm{s}$ encountered during the study. 
Test 2. Outdoor air dampers closed

In order to determine how much air leakage was through outdoor air dampers, a tracer-gas study was performed with outdoor dampers closed. The results of air exchange rate measurements with dampers closed are shown in Table 3. Fig. 3 shows the results of this experiment compared with the results the previous study. The average air exchange rate was $1.2 \mathrm{~h}-1$ an average temperature difference of $8.20 \mathrm{C}$ and an average wind speed of $1.7 \mathrm{~m} / \mathrm{s}$. Two distinct temperature difference regimes make up this study: 1) small $\Delta T$ ( 4 data points below 20C), and 2) 1 arge $\Delta T$ ( 6 data points between 11 and $17 \circ \mathrm{C}$ ). There are no data directly comparable to the first regime in the study under normal fan operation, but there are 20 points in the large $\Delta T$ region. The two large $\Delta \mathrm{T}$ results are nearly identical: an air exchange rate of $1.1 \pm 0.2 \mathrm{~h}-1$ at a temperature difference of $13.40 \mathrm{C}$ and wind speed of $1.6 \mathrm{~m} / \mathrm{s}$ with dampers closed, compared with an air exchange rate of $1.0 \pm 0.3 \mathrm{~h}^{-1}$ at a temperature difference of $13.50 \mathrm{C}$ and $\mathrm{w}$ ind speed of $2.8 \mathrm{~m} / \mathrm{s}$.

As in the case of normal HVAC-system operation, the large data scatter make it difficult to assign a definite relationship between $\Delta T$ and $I$. In the present instance, neither a direct nor inverse dependence, nor independence of $\Delta T$ and $I$ can be excluded. The standard error bands are not drawn, but are so wide that they encompass the origin and most of the normal HVAC-system operation data. The combined normal HVAC-sy stem operation and damperclosed data are about as well fit by $I=1 h^{-1}$ as by any other relationship.

Test 3. Fans off and dampers closed

In order to determine how much the HVAC system contributes to air leakage, a tracer-gas test was done in which fans were turned on only at the beginning and end in order to mix the air, but left of $f$ in the middle of the test for about two hours. During this time, outdoor air dampers were also closed. An air exchange rate could not be calculated from the data obtained by this test because nearly all the gas ended up in zone 8 immediately after injection.

Test 4. Air leakage from the office and public areas to the stack areas

It was determined from information supplied by GSA that airhandling systems $6-9$ serve mainly the stacks, while systems $1-5$ serve mainly the remainder of the building (Fig. 2). Therefore, tracer gas was injected only into zones 1 to 5 in order to test whether there was significant air leakage into the stack areas from the rest of the building. It was found that there was immediate, thorough mixing between the stack and non-stack areas. The tracer gas concentrations in the nine zones were so uniform during the test, in fact, that it was possible to calculate an air exchange rate for the building (see Fig. 3 and Table 2, 
Test 5. Fan pressurization measurements

Fan pressurization measurements were performed in order to measure the intrinsic weather-independent envelope tightness of the building. The building was pressurized by closing off all exhaust air dampers and return fans, including those serving the garage, and opening all supply air dampers and fans. Concentration measurements were made in two stack areas on the 7 th and 14 th stack floors. (There are 21 stack floors.) The building could be pressurized to maximum pressure differences of only $14 \mathrm{~Pa}$, measured at the Constitution Avenue entrance on the ground floor (corresponding to the fifth stack floor) and $10 \mathrm{~Pa}$ at the Pennsylvania Avenue entrance on the main floor

(corresponding to the third stack floor). It was noticed during the test that there were strong drafts from the garage through two doorways into the main body of the building. The average temperature difference during the test was $5.90^{\circ} \mathrm{C}$ and the average wind speed was $1.5 \mathrm{~m} / \mathrm{s}$.

The air exchange rate calculated by the constant concentration method (equation 2) was $1.5 \mathrm{~h}^{-1}$. Air exchange rates were also calculated by the concentration-decay method (equation 1) for two hours. As shown in. Table 4, these air exchange rates were $0.0 \mathrm{~h}^{-1}$ for the 14 th floor for both hours and 0.1 and $0.4 \mathrm{~h}^{-1}$ for the $7 \mathrm{th}$ floor. The rates calculated by the concentration decay method may even be lower than expected in the absence of pressurization (Fig. 3).

\section{CONCLUSIONS AND RECOMMENDATIONS}

Air exchange measurements were taken under various combinations of temperature and wind speed. The average air exchange rate was $0.9 \mathrm{~h}^{-1}$ for an average temperature difference of $11.3^{\circ} \mathrm{C}$ and an average wind speed of $2.7 \mathrm{~m} / \mathrm{s}$. The indoor temperature was very nearly constant at around $23^{\circ} \mathrm{C}$ and the outdoor temperature was always lower than the indoor temperature. No clear dependence of air exchange rate on temperature differences up to $17^{\circ} \mathrm{C}$ or wind speeds up to $5 \mathrm{~m} / \mathrm{s}$ was found. If a more complete assessment of the National Archives Building is desired, then further air exchange rate measurements would need to be taken at different times of the year, and at higher wind speeds than those encountered during the tests.

The test done with air dampers closed and fans operating showed that at a temperature difference between 11 and $170 \mathrm{C}$, the air exchange rate was the same as that when dampers were operating automatically. This may be because under normal operation of the HVAC system, dampers would be closed at these outdoor temperatures. It would be useful to conduct this type of test under different weather conditions and record damper opening and closing.

The test with dampers closed and fans of $\mathrm{fesulted}$ in tracer gas ending up in one zone (8), so no useful results could be obtained. 
A test of interzone air movement showed that air migrates rapidly from non-stack to stack areas with fans operating normally.

The building could not be pressurized beyond an indooroutdoor pressure difference of $14 \mathrm{~Pa}$. There was some doubt about the resulting air exchange rate obtained at this pressure difference since a rate of $1.5 \mathrm{~h}-1$ was obtained by the constant concentration method and rates under $0.5 \mathrm{~h}^{-1}$ were obtained by the tracer-gas decay method. The first air exchange rate seems more likely because it is at least higher than air exchange rates in the absence of pressurization.

There are uncertainties as to the exact areas served by the various air-handling systems (Fig. 2) and this tubing and wiring could prove invaluable in accurately charting the building. For this reason, and to conduct further tests described below, it is recommended that the tubing and wiring be left in place.

A similar study of eight new GSA buildings in various parts of the United States (unpublished data) shows that the Archives Building is about twice as leaky as new office buildings, both under normal operation of the HVAC system and under pressurization. Their air exchange rates under normal operation of the HVAC systems vary from 0.2 to $0.6 \mathrm{~h}^{-1}$ for outdoor temperatures of $4-10^{\circ} \mathrm{C}$ and wind speeds under $1.3 \mathrm{~m} / \mathrm{s}$. Their air exchange rates at a pressure difference of $14 \mathrm{~Pa}$ were 0.5 to 0.9 $n-1$.

\section{ACKNOWLEDGMENT}

We wish to thank Ron Diggs, Lewis Johnson, Louis Olsen, Dan Poyner, and Joe Schaefer of GSA for their invaluable assistance in carrying out the tests.

\section{REFERENCES}

1. R. A. Grot, C. M. Hunt and D. Harrje, "Tracer gas automated equipment for complex building studies," pp. 103-128 in "First Air Infiltration Center (AIC) Conference: Air infiltration and measuring techniques, Proceedings," AIC, Bracknell, UK, 1980.

2. S. Silberstein, "Air leakage measurements of an unpartitioned mobile home," National Bureau of Standards Interagency Report 802105, Washington, 1980. 
TABLE 1. Air Handling System Flow Rates and Air Exchange Rate Weighting Factors.

$\begin{array}{cccc}\text { System } & \begin{array}{c}\mathrm{Flow} \text { rate } \\ \text { cf } \mathrm{m}, \mathrm{m} / \mathrm{s}\end{array} & \begin{array}{c}\text { Air exchange rate } \\ \text { weighting factor }\end{array} \\ 1 & 100 & 1 \\ 2 & 69 & 33 & 0.09 \\ 3 & 5.9 & 2.8 & 1 \\ 4 & 62 & 29 & 0.09 \\ 5 & 5.9 & 2.8 & 0.6 \\ 6 & 40 & 19 & 1 \\ 7 & 70 & 33 & 1 \\ 8 & 65 & 31 & 1 \\ 9 & 66 & 31 & 1\end{array}$


TABLE 2. Air Exchange Rates under Normal HVAC-System Operation

\section{LEGEND}

W SPEED $=$ wind speed, $\mathrm{m} / \mathrm{s}$

W $D I R=$ wind direction, degrees clockwise from north

T-OUT = outdoor temperature, OC

$\mathrm{T}-\mathrm{IN}=$ average indoor temperature, ${ }^{\circ} \mathrm{C}$

$T-D I F F=T-I N-T-O U T, O C$

$A E R$ = average air exchange rate, $h-1$

(weighting factors in Table 1)

RET = return air fan

$\begin{array}{cccccccc}\text { DATE } & \text { HOUR } & \text { W SPEED } & \text { W DIR } & \text { T-OUT } & \text { T-IN } & \text { T-DIFF } & \text { AER } \\ 3 / 24 / 83 & 18 & 2.2 & 45.0 & 7.7 & 22.4 & 14.7 & 1.23\end{array}$

RET $1=1.44$
RET $2=1.14$
RET $3=1.63$
RET $4=1.52$
RET $5=1.83$
RET $6=1.88$
RET $7=1.20$
RET $8=1.20$
RET $9=1.22$

DATE HOUR W SPEED W DIR

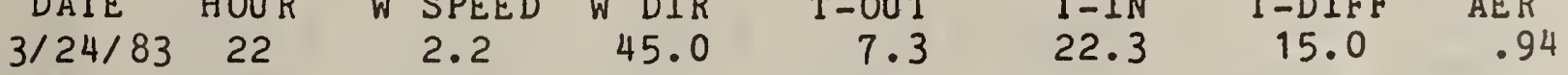

$\operatorname{RET} 1=1.04$
$\operatorname{RET} 2=1.39$
$\operatorname{RET} 3=1.36$
$\operatorname{RET} 4=1.36$
$\operatorname{RET} 5=1.91$
$\operatorname{RET} 6=.60$
$\operatorname{RET} 7=.66$
$\operatorname{RET} 8=1.58$
$\operatorname{RET} 9=1.37$

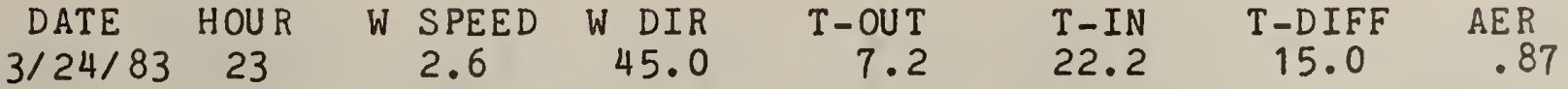

RET $1=1.41$
RET $2=1.40$
RET $3=1.33$
RET $4=1.15$
RET $5=.77$
RET $6=.70$
RET $7=.51$
RET $8=.62$
RET $9=.66$


TABLE 2 (continued)

$\begin{aligned} & \begin{array}{c}\text { DATE } \\ 3 / 25 / 83 \text { HOUR } \\ 1\end{array} \text { W SPEED } \\ & \text { RET 1 }=1.0 \\ & \text { RET 2 }=1.34 \\ & \text { RET 3 }=1.64 \\ & \text { RET 4 }=1.38 \\ & \text { RET } 5= .77 \\ & \text { RET } 6=1.56 \\ & \text { RET } 7=2.13 \\ & \text { RET } 8=2.19 \\ & \text { RET } 9=1.90\end{aligned}$

\begin{tabular}{|c|c|c|c|}
\hline $\begin{array}{c}\text { DATE } \\
3 / 25 / 83\end{array}$ & $\begin{array}{c}\text { HOU R } \\
8\end{array}$ & $W$ & $\begin{array}{l}\text { SPEED } \\
2.7\end{array}$ \\
\hline & $\begin{array}{ll}\text { RET } & 1 \\
\text { RET } & 2 \\
\text { RET } & 3 \\
\text { RET } & 4 \\
\text { RET } & 5 \\
\text { RET } & 6 \\
\text { RET } & 7 \\
\text { RET } & 8 \\
\text { RET } & 9\end{array}$ & $\begin{array}{l}= \\
= \\
= \\
= \\
= \\
= \\
= \\
= \\
=\end{array}$ & $\begin{array}{r}1.16 \\
1.05 \\
1.01 \\
1.03 \\
.67 \\
.59 \\
.85 \\
.81 \\
.73\end{array}$ \\
\hline
\end{tabular}

DATE HOUR W SPEED

$\begin{array}{rl}3 / 25 / 83 \quad 9 & 2.8 \\ \text { RET } 1= & 1.48 \\ \text { RET } 2=1.72 \\ \text { RET } 3=1.75 \\ \text { RET } 4=1.53 \\ \text { RET } 5=1.74 \\ \text { RET } 6=1.32 \\ \text { RET } 7=1.64 \\ \text { RET } 8=1.50 \\ \text { RET } 9=1.24\end{array}$

$\begin{array}{cccccccc}\text { DATE } & \text { HOUR } & \text { W SPEED } & \text { W DIR } & \text { T-OUT } & \text { T-IN } & \text { T-DIFF } & \text { AER } \\ 3 / 25 / 83 & 14 & 2.7 & 112.5 & 8.4 & 22.4 & 14.0 & 1.29\end{array}$

RET $1=1.38$
RET $2=1.26$
RET $3=1.73$
$\operatorname{RET} 4=1.49$
$\operatorname{RET} 5=.71$
$\operatorname{RET} 6=1.90$
$\operatorname{RET} 7=1.48$
$\operatorname{RET} 8=1.58$
$\operatorname{RET} 9=1.00$


TABLE 2 (continued)

\begin{tabular}{|c|c|c|c|c|c|c|c|c|}
\hline \multirow[t]{2}{*}{$\begin{array}{c}\text { DATE } \\
3 / 25 / 83\end{array}$} & $\begin{array}{l}\text { HOUR } \\
15\end{array}$ & W & $\begin{array}{l}\text { SPEED } \\
2.9\end{array}$ & $\begin{array}{r}\text { W DIR } \\
90.0\end{array}$ & $\begin{array}{r}\text { T-OUT } \\
8.9\end{array}$ & $\begin{array}{l}T-I N \\
22.4\end{array}$ & $\begin{array}{c}T-D I F F \\
13.5\end{array}$ & $\begin{array}{l}\text { AER } \\
1.32\end{array}$ \\
\hline & $\begin{array}{ll}\text { RET } & 1 \\
\text { RET } & 2 \\
\text { RET } & 3 \\
\text { RET } & 4 \\
\text { RET } & 5 \\
\text { RET } & 6 \\
\text { RET } & 7 \\
\text { RET } & 8 \\
\text { RET } & 9\end{array}$ & $\begin{array}{l}= \\
= \\
= \\
= \\
= \\
= \\
= \\
= \\
=\end{array}$ & $\begin{array}{r}1.98 \\
1.54 \\
1.97 \\
1.45 \\
.52 \\
.97 \\
1.39 \\
1.48 \\
.58\end{array}$ & & & & & \\
\hline \multirow[t]{2}{*}{$\begin{array}{c}\text { DATE } \\
4 / 1 / 83\end{array}$} & $\begin{array}{c}\text { HOUR } \\
18\end{array}$ & $W^{\top}$ & $\begin{array}{l}\text { SPEED } \\
1.5\end{array}$ & $\begin{array}{l}\text { W DIR } \\
180.0\end{array}$ & $\begin{array}{r}T-O U T \\
14.8\end{array}$ & $\begin{array}{l}T-I N \\
23.4\end{array}$ & $\begin{array}{c}T-D I F F \\
8.6\end{array}$ & $\begin{array}{l}\text { AER } \\
1.09\end{array}$ \\
\hline & $\begin{array}{ll}\text { RET } & 1 \\
\text { RET } & 2 \\
\text { RET } & 3 \\
\text { RET } & 4 \\
\text { RET } & 5 \\
\text { RET } & 6 \\
\text { RET } & 7 \\
\text { RET } & 8 \\
\text { RET } & 9\end{array}$ & $\begin{array}{l}= \\
= \\
= \\
= \\
= \\
= \\
= \\
= \\
=\end{array}$ & $\begin{array}{r}1.70 \\
1.92 \\
2.72 \\
1.33 \\
.36 \\
0.00 \\
.22 \\
.44 \\
1.81\end{array}$ & & & & & \\
\hline \multirow[t]{2}{*}{$\begin{array}{c}\text { DATE } \\
4 / 2 / 83\end{array}$} & $\begin{array}{c}\text { HOU R } \\
2\end{array}$ & W & $\begin{array}{l}\text { SPEED } \\
.6\end{array}$ & $\begin{array}{r}\text { W DIR } \\
67.5\end{array}$ & $\begin{array}{r}\text { T-OU T } \\
10.9\end{array}$ & $\begin{array}{l}T-I N \\
23.2\end{array}$ & $\begin{array}{c}\text { T-DIFF } \\
12.3\end{array}$ & $\begin{array}{l}\text { AER } \\
.81\end{array}$ \\
\hline & $\begin{array}{ll}\text { RET } & 1 \\
\text { RET } & 2 \\
\text { RET } & 3 \\
\text { RET } & 4 \\
\text { RET } & 5 \\
\text { RET } & 6 \\
\text { RET } & 7 \\
\text { RET } & 8 \\
\text { RET } & 9\end{array}$ & $\begin{array}{l}= \\
= \\
= \\
= \\
= \\
= \\
= \\
= \\
=\end{array}$ & $\begin{array}{r}1.36 \\
2.30 \\
1.30 \\
.32 \\
.39 \\
.16 \\
.60 \\
.49 \\
1.13\end{array}$ & & & & & \\
\hline \multirow[t]{2}{*}{$\begin{array}{c}\text { DATE } \\
4 / 14 / 83\end{array}$} & $\begin{array}{c}\text { HOU R } \\
13\end{array}$ & $W$ & $\begin{array}{l}\text { SPEED } \\
2.6\end{array}$ & $\begin{array}{l}\text { W DIR } \\
157.5\end{array}$ & $\begin{array}{r}\mathrm{T}-\mathrm{OUT} \\
18.5\end{array}$ & $\begin{array}{l}T-I N \\
23.0\end{array}$ & $\begin{array}{c}T-D I F F \\
4.5\end{array}$ & $\begin{array}{l}\text { AER } \\
.48\end{array}$ \\
\hline & $\begin{array}{ll}\mathrm{RET} & 1 \\
\mathrm{RET} & 2 \\
\mathrm{RET} & 3 \\
\mathrm{RET} & 4 \\
\mathrm{RET} & 5 \\
\mathrm{RET} & 6 \\
\mathrm{RET} & 7 \\
\mathrm{RET} & 8 \\
\mathrm{RET} & 9\end{array}$ & $\begin{array}{l}= \\
= \\
= \\
= \\
= \\
= \\
= \\
= \\
=\end{array}$ & $\begin{array}{r}.91 \\
.43 \\
0.00 \\
.26 \\
0.00 \\
.66 \\
.45 \\
.61 \\
.57\end{array}$ & & & t. & & \\
\hline
\end{tabular}


TABLE 2 (continued)

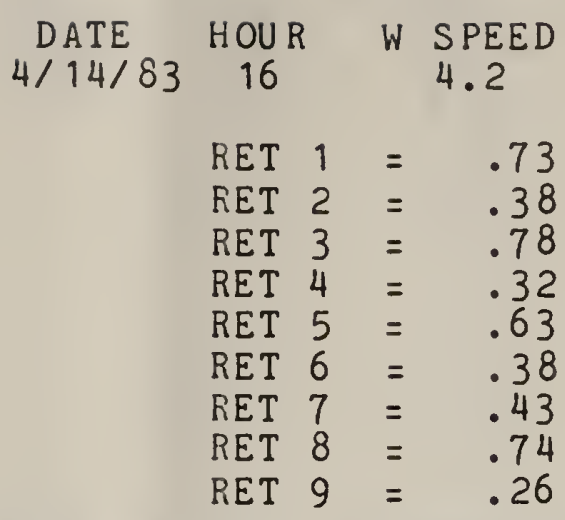

DATE HOUR W SPEED 4/14/83

$$
3.3
$$

W DIR

135.0

T - IN

23.0

T-DIFF AER

16.4

T - IN
22.8

T-DIFF

AER

.55

RET 1 $=1.98$
$\operatorname{RET} 2=.55$
$\operatorname{RET} 3=.80$
$\operatorname{RET} 4=.51$
$\operatorname{RET} 5=.54$
$\operatorname{RET} 6=.47$
$\operatorname{RET} 7=.58$
$\operatorname{RET} 8=1.37$
$\operatorname{RET} 9=.70$

DATE HOUR W SPEED 4/14/83

$$
2.1
$$

W DIR

135.0

T - OU T

16.1

T-IN

23.0

T-DIFF

6.9

AER

RET $1=1.92$

RET $2=.49$

RET $3=.57$

RET $4=.70$

RET $5=.74$

RET $6=.60$

RET $7=.56$

RET $8=1.58$

RET $9=.34$

DATE HOUR W SPEED 4/15/83

RET $1=2.20$
RET $2=1.76$
RET $3=1.18$
RET $4=.31$
RET $5=.30$
RET $6=.31$
RET $7=.76$
RET $8=.68$
RET $9=.82$


TABLE 2 (continued)

\begin{tabular}{|c|c|c|c|c|c|c|c|c|}
\hline \multirow[t]{2}{*}{$\begin{array}{l}\text { DATE } \\
4 / 15 / 83\end{array}$} & $\underset{4}{\mathrm{HOUR}}$ & W & $\begin{array}{l}\text { SPEED } \\
1.9\end{array}$ & $\begin{array}{l}\text { W DIR } \\
157.5\end{array}$ & $\begin{array}{r}\mathrm{T} \text {-OUT } \\
16.6\end{array}$ & $\begin{array}{l}T-I N \\
23.1\end{array}$ & $\begin{array}{c}T-D I F F \\
6.5\end{array}$ & $\begin{array}{l}\text { AER } \\
.91\end{array}$ \\
\hline & $\begin{array}{ll}\text { RET } & 1 \\
\text { RET } & 2 \\
\operatorname{RET} & 3 \\
\text { RET } & 4 \\
\operatorname{RET} & 5 \\
\operatorname{RET} & 6 \\
\operatorname{RET} & 7 \\
\operatorname{RET} & 8 \\
\text { RET } & 9\end{array}$ & $\begin{array}{l}= \\
= \\
= \\
= \\
= \\
= \\
= \\
=\end{array}$ & $\begin{array}{r}1.37 \\
.32 \\
1.06 \\
.49 \\
.53 \\
.89 \\
.41 \\
1.20 \\
.84\end{array}$ & & & & & \\
\hline \multirow[t]{2}{*}{$\begin{array}{c}\text { DATE } \\
4 / 15 / 83\end{array}$} & $\begin{array}{c}\text { HOU R } \\
7\end{array}$ & W & $\begin{array}{l}\text { SPEED } \\
2.6\end{array}$ & $\begin{array}{l}\text { W DIR } \\
157.5\end{array}$ & $\begin{array}{r}T-O U T \\
17.7\end{array}$ & $\begin{array}{l}T-I N \\
23.2\end{array}$ & $\begin{array}{c}T-D I F F \\
5.5\end{array}$ & $\begin{array}{l}\text { AER } \\
.54\end{array}$ \\
\hline & $\begin{array}{ll}\text { RET } & 1 \\
\operatorname{RET} & 2 \\
\text { RET } & 3 \\
\text { RET } & 4 \\
\operatorname{RET} & 5 \\
\operatorname{RET} & 6 \\
\operatorname{RET} & 7 \\
\operatorname{RET} & 8 \\
\text { RET } & 9\end{array}$ & $\begin{array}{l}= \\
= \\
= \\
= \\
= \\
= \\
= \\
=\end{array}$ & $\begin{array}{r}1.26 \\
.70 \\
.42 \\
.63 \\
.47 \\
.46 \\
.47 \\
.29 \\
.34\end{array}$ & & & & & \\
\hline \multirow[t]{2}{*}{$\begin{array}{c}\text { DATE } \\
4 / 15 / 83\end{array}$} & $\begin{array}{l}\text { HOU R } \\
10\end{array}$ & W & $\begin{array}{l}\text { SPEE D } \\
2.3\end{array}$ & $\begin{array}{l}\text { W DIR } \\
180.0\end{array}$ & $\begin{array}{r}T-O U T \\
18.6\end{array}$ & $\begin{array}{l}T-I N \\
23.7\end{array}$ & $\begin{array}{c}T-D I F F \\
5.1\end{array}$ & $\begin{array}{l}\text { AER } \\
.71\end{array}$ \\
\hline & $\begin{array}{ll}\text { RET } & 1 \\
\text { RET } & 2 \\
\operatorname{RET} & 3 \\
\operatorname{RET} & 4 \\
\operatorname{RET} & 5 \\
\operatorname{RET} & 6 \\
\operatorname{RET} & 7 \\
\operatorname{RET} & 8 \\
\operatorname{RET} & 9\end{array}$ & $\begin{array}{l}= \\
= \\
= \\
= \\
= \\
= \\
= \\
= \\
=\end{array}$ & $\begin{array}{r}1.48 \\
.71 \\
.35 \\
.48 \\
.82 \\
.65 \\
.53 \\
.58 \\
.64\end{array}$ & & & & 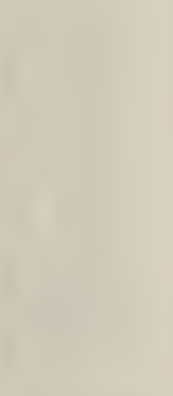 & \\
\hline \multirow[t]{2}{*}{$\begin{array}{c}\text { DATE } \\
4 / 18 / 83\end{array}$} & $\begin{array}{c}\mathrm{HOUR} \\
4\end{array}$ & W & $\begin{array}{l}\text { SPEED } \\
2.5\end{array}$ & $\begin{array}{l}\text { W DIR } \\
292.5\end{array}$ & $\begin{array}{r}\mathrm{T} \text { - OUT } \\
9.7\end{array}$ & $\begin{array}{l}T-I N \\
22.2\end{array}$ & $\begin{array}{c}T-D I F F \\
12.5\end{array}$ & $\begin{array}{l}\text { AER } \\
1.02\end{array}$ \\
\hline & $\begin{array}{ll}\operatorname{RET} & 1 \\
\operatorname{RET} & 2 \\
\operatorname{RET} & 3 \\
\operatorname{RET} & 4 \\
\operatorname{RET} & 5 \\
\operatorname{RET} & 6 \\
\operatorname{RET} & 7 \\
\operatorname{RET} & 8 \\
\operatorname{RET} & 9\end{array}$ & $\begin{array}{l}= \\
= \\
= \\
= \\
= \\
= \\
= \\
= \\
=\end{array}$ & $\begin{array}{r}1.48 \\
0.00 \\
1.70 \\
.14 \\
.93 \\
.95 \\
.88 \\
.38 \\
.98\end{array}$ & & & & & \\
\hline
\end{tabular}


TABLE 2 (continued)

\begin{tabular}{|c|c|c|c|c|c|c|c|c|}
\hline \multirow[t]{2}{*}{$\begin{array}{l}\text { DATE } \\
4 / 18 / 83\end{array}$} & $\begin{array}{l}\mathrm{HOUR} R \\
7\end{array}$ & $w$ & $\begin{array}{l}\text { SPEED } \\
2.3\end{array}$ & $\begin{array}{l}\text { W DIR } \\
292.5\end{array}$ & $\begin{array}{r}\mathrm{T}-\mathrm{OUT} \\
10.8\end{array}$ & $\begin{array}{l}T-I N \\
22.3\end{array}$ & $\begin{array}{c}T-D I F F \\
11.5\end{array}$ & $\begin{array}{l}\text { AER } \\
1.24\end{array}$ \\
\hline & $\begin{array}{ll}\text { RET } & 1 \\
\text { RET } & 2 \\
\text { RET } & 3 \\
\text { RET } & 4 \\
\text { RET } & 5 \\
\text { RET } & 6 \\
\text { RET } & 7 \\
\text { RET } & 8 \\
\text { RET } & 9\end{array}$ & $\begin{array}{l}= \\
= \\
= \\
= \\
= \\
= \\
= \\
= \\
=\end{array}$ & $\begin{array}{r}.71 \\
.90 \\
.91 \\
1.46 \\
.71 \\
.49 \\
1.44 \\
2.55 \\
1.69\end{array}$ & & & . & & \\
\hline \multirow[t]{2}{*}{$\begin{array}{c}\text { DATE } \\
4 / 18 / 83\end{array}$} & $\begin{array}{c}\text { HOU R } \\
10\end{array}$ & $\mathrm{w}$ & $\begin{array}{l}\text { SPEED } \\
2.0\end{array}$ & $\begin{array}{l}\text { W DIR } \\
270.0\end{array}$ & $\begin{array}{r}\mathrm{T}-\mathrm{OUT} \\
10.0\end{array}$ & $\begin{array}{l}T-I N \\
22.8\end{array}$ & $\begin{array}{c}T-D I F F \\
12.8\end{array}$ & $\begin{array}{l}\text { AER } \\
.74\end{array}$ \\
\hline & $\begin{array}{ll}\text { RET } & 1 \\
\text { RET } & 2 \\
\text { RET } & 3 \\
\text { RET } & 4 \\
\text { RET } & 5 \\
\text { RET } & 6 \\
\text { RET } & 7 \\
\text { RET } & 8 \\
\text { RET } & 9\end{array}$ & $\begin{array}{l}= \\
= \\
= \\
= \\
= \\
= \\
= \\
=\end{array}$ & $\begin{array}{r}.84 \\
.71 \\
1.12 \\
.35 \\
.38 \\
.79 \\
.80 \\
.58 \\
.53\end{array}$ & & & & & \\
\hline \multirow[t]{2}{*}{$\begin{array}{c}\text { DATE } \\
4 / 18 / 83\end{array}$} & $\begin{array}{c}\text { HOU R } \\
13\end{array}$ & $W$ & $\begin{array}{l}\text { SPEED } \\
1.8\end{array}$ & $\begin{array}{l}\text { W DIR } \\
270.0\end{array}$ & $\begin{array}{l}\mathrm{T}-\text { OUT } \\
11.9\end{array}$ & $\begin{array}{l}T-I N \\
23.0\end{array}$ & $\begin{array}{c}T-D I F F \\
11.1\end{array}$ & $\begin{array}{l}\text { AER } \\
.86\end{array}$ \\
\hline & $\begin{array}{ll}\operatorname{RET} & 1 \\
\operatorname{RET} & 2 \\
\operatorname{RET} & 3 \\
\operatorname{RET} & 4 \\
\operatorname{RET} & 5 \\
\operatorname{RET} & 6 \\
\operatorname{RET} & 7 \\
\operatorname{RET} & 8 \\
\operatorname{RET} & 9\end{array}$ & $\begin{array}{l}= \\
= \\
= \\
= \\
= \\
= \\
=\end{array}$ & $\begin{array}{r}1.46 \\
1.56 \\
1.00 \\
.48 \\
0.00 \\
.62 \\
.31 \\
1.19 \\
1.10\end{array}$ & & & & & \\
\hline \multirow[t]{2}{*}{$\begin{array}{c}\text { DATE } \\
4 / 18 / 83\end{array}$} & $\begin{array}{c}\text { HOU R } \\
22\end{array}$ & W & $\begin{array}{l}\text { SPEE D } \\
2.1\end{array}$ & $\begin{array}{r}\text { W DIR } \\
67.5\end{array}$ & $\begin{array}{l}\text { T-OU T } \\
11.1\end{array}$ & $\begin{array}{l}T-I N \\
22.9\end{array}$ & $\begin{array}{c}T-D I F F \\
11.8\end{array}$ & $\begin{array}{l}\text { AER } \\
.62\end{array}$ \\
\hline & $\begin{array}{ll}\operatorname{RET} & 1 \\
\operatorname{RET} & 2 \\
\operatorname{RET} & 3 \\
\operatorname{RET} & 4 \\
\operatorname{RET} & 5 \\
\operatorname{RET} & 6 \\
\operatorname{RET} & 7 \\
\operatorname{RET} & 8 \\
\operatorname{RET} & 9\end{array}$ & $\begin{array}{l}= \\
= \\
= \\
= \\
= \\
= \\
= \\
=\end{array}$ & $\begin{array}{r}.47 \\
.32 \\
1.01 \\
.74 \\
.72 \\
.13 \\
.56 \\
.56 \\
.92\end{array}$ & & & & & \\
\hline
\end{tabular}




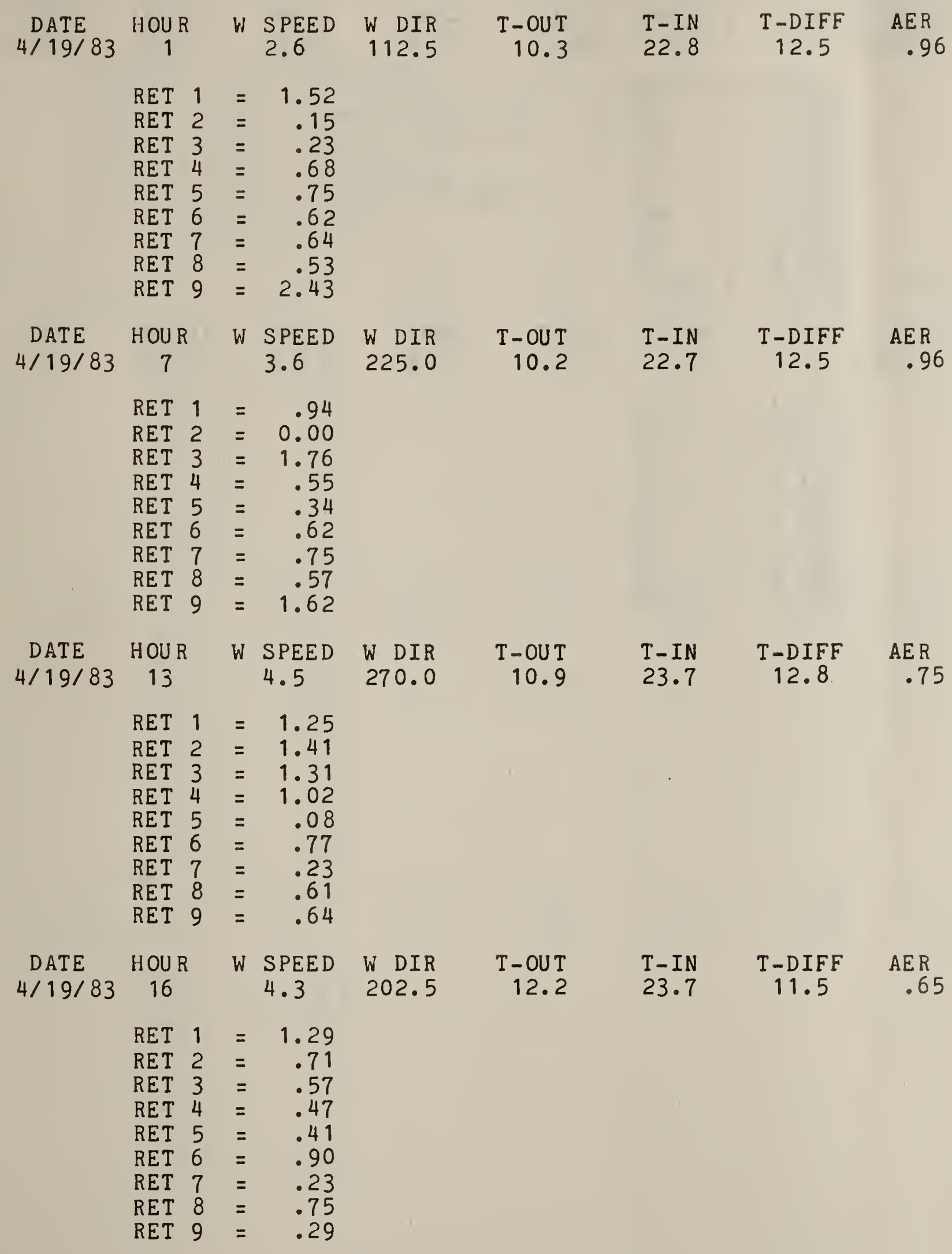


TABLE 2 (continued)

\begin{tabular}{|c|c|c|c|c|c|c|c|c|}
\hline \multirow[t]{2}{*}{$\begin{array}{c}\text { DATE } \\
4 / 19 / 83\end{array}$} & $\begin{array}{l}\text { HOU R } \\
19\end{array}$ & W & $\begin{array}{l}\text { SPEED } \\
5.0\end{array}$ & $\begin{array}{l}\text { W DIR } \\
292.5\end{array}$ & $\begin{array}{r}T \text {-OUT } \\
9.6\end{array}$ & $\begin{array}{l}T-I N \\
23.4\end{array}$ & $\begin{array}{c}T-D I F F \\
13.8\end{array}$ & $\begin{array}{l}\text { AER } \\
.68\end{array}$ \\
\hline & $\begin{array}{ll}\operatorname{RET} & 1 \\
\operatorname{RET} & 2 \\
\operatorname{RET} & 3 \\
\operatorname{RET} & 4 \\
\operatorname{RET} & 5 \\
\operatorname{RET} & 6 \\
\operatorname{RET} & 7 \\
\operatorname{RET} & 8 \\
\operatorname{RET} & 9\end{array}$ & $\begin{array}{l}= \\
= \\
= \\
= \\
= \\
= \\
= \\
= \\
=\end{array}$ & $\begin{array}{r}1.10 \\
.01 \\
.49 \\
.62 \\
.33 \\
.40 \\
.48 \\
.55 \\
1.35\end{array}$ & & & & & \\
\hline \multirow[t]{2}{*}{$\begin{array}{c}\text { DATE } \\
4 / 19 / 83\end{array}$} & $\begin{array}{l}\text { HOU R } \\
22\end{array}$ & $\mathrm{~W}$ & $\begin{array}{l}\text { SPEED } \\
4.1\end{array}$ & $\begin{array}{l}\text { W DIR } \\
292.5\end{array}$ & $\begin{array}{r}T-O U T \\
8.6\end{array}$ & $\begin{array}{l}\mathrm{T}-\mathrm{IN} \\
23.2\end{array}$ & $\begin{array}{c}T-D I F F \\
14.6\end{array}$ & $\begin{array}{l}\text { AER } \\
.59\end{array}$ \\
\hline & $\begin{array}{ll}\text { RET } & 1 \\
\text { RET } & 2 \\
\text { RET } & 3 \\
\text { RET } & 4 \\
\text { RET } & 5 \\
\text { RET } & 6 \\
\text { RET } & 7 \\
\text { RET } & 8 \\
\text { RET } & 9\end{array}$ & $\begin{array}{l}= \\
= \\
= \\
= \\
= \\
= \\
= \\
=\end{array}$ & $\begin{array}{r}1.02 \\
1.13 \\
.73 \\
.73 \\
.61 \\
.75 \\
.35 \\
.59 \\
.06\end{array}$ & & & & & \\
\hline
\end{tabular}


TABLE 3. Air Exchange Rates with Fans of $f$ and Outdoor Dampers Closed LEGEND

W SPEED = wind speed, $\mathrm{m} / \mathrm{s}$

$W D I R=$ wind direction, degrees clockwise from north

T-OUT = outdoor temperature, OC

$\mathrm{T}-\mathrm{IN}=$ average indoor temperature, ${ }^{\circ} \mathrm{C}$

$T-D I F F=T-I N-T-O U T, O C$

$A E R=$ average air exchange rate, $h-1$

(weighting factors in Table 1)

RET = return air fan

\begin{tabular}{|c|c|c|c|}
\hline $\begin{array}{c}\text { DATE } \\
3 / 25 / 83\end{array}$ & $\begin{array}{l}\text { HOUR } \\
18\end{array}$ & $W^{\prime}$ & $\begin{array}{l}\text { SPEED } \\
2.1\end{array}$ \\
\hline & $\begin{array}{ll}\text { RET } & 1 \\
\text { RET } & 2 \\
\text { RET } & 3 \\
\text { RET } & 4 \\
\text { RET } & 5 \\
\text { RET } & 6 \\
\text { RET } & 7 \\
\text { RET } & 8 \\
\text { RET } & 9\end{array}$ & $\begin{array}{l}= \\
= \\
= \\
= \\
= \\
= \\
=\end{array}$ & $\begin{array}{r}2.01 \\
1.05 \\
1.13 \\
.99 \\
.46 \\
.26 \\
.81 \\
.50 \\
.64\end{array}$ \\
\hline
\end{tabular}

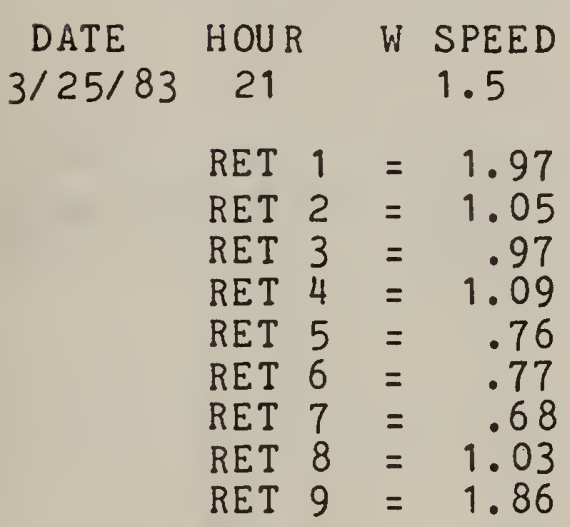

DATE HOUR W SPEED

$3 / 25 / 83 \quad 22$

1.6

W DIR

T-OUT

9.7

T - IN

22.2

T-DIFF AER

$12.5 \quad 1.17$

T-DIFF AER

$\begin{array}{lll}22.5 & 12.9 & .86\end{array}$

$\begin{array}{rrcc}- \text { OUT } & \text { T IN } & & \\ 9.6 & 22.5 & 12.9 & .86\end{array}$
6 
TABLE 3 (continued)

$\begin{array}{rlrl}\begin{array}{c}\text { DATE } \\ 3 / 25 / 83\end{array} & \begin{array}{c}\text { HOUR } \\ 23\end{array} & \text { W SPEED } \\ 1.6\end{array}$

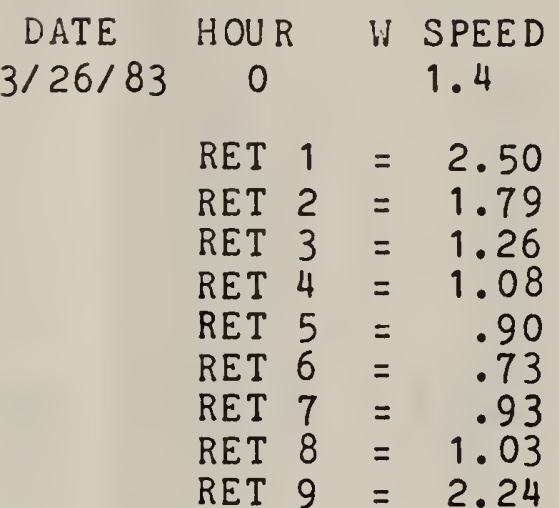

DATE HOUR W SPEED $3 / 26 / 83 \quad 2 \quad 1.1$

W DIR
45.0

$T-$ OUT
8.5

T - IN

22.1

T-DIFF

13.6

AER

1.14

$\operatorname{RET} 1=1.80$
$\operatorname{RET} 2=1.43$
$\operatorname{RET} 3=1.31$
$\operatorname{RET} 4=1.11$
$\operatorname{RET} 5=1.84$
$\operatorname{RET} 6=.68$
$\operatorname{RET} 7=.87$
$\operatorname{RET} 8=1.73$
$\operatorname{RET} 9=1.64$

RET $1=2.10$
RET $2=2.16$
RET $3=1.78$
RET $4=1.10$
RET $5=.43$
RET $6=.49$
$\operatorname{RET~} 7=.54$
$\operatorname{RET} 8=98$
$\operatorname{RET} 9=1.14$

DATE HOUR W SPEED 3/27/83

RET $1=1.79$
RET 2 $=1.79$
RET $3=2.07$
RET $4=1.63$
RET $5=.46$
RET $6=1.81$
RET $7=1.94$
RET $8=1.95$
RET $9=19$

W DIR

90.0

$T-$ OU T
6.4

$T-I N$
21.4

T-DIFF

15.0

AER

.97 
TABLE 3 (continued)

\begin{tabular}{|c|c|c|c|c|c|c|c|c|}
\hline \multirow[t]{2}{*}{$\begin{array}{c}\text { DATE } \\
3 / 27 / 83\end{array}$} & $\begin{array}{c}\text { HOU R } \\
18\end{array}$ & $W$ & $\begin{array}{l}\text { SPEED } \\
1.1\end{array}$ & $\begin{array}{l}\text { W DIR } \\
270.0\end{array}$ & $\begin{array}{r}T-O U T \\
19.6\end{array}$ & $\begin{array}{l}T-I N \\
19.9\end{array}$ & $\begin{array}{c}T-D I F F \\
.3\end{array}$ & $\begin{array}{l}\text { AER } \\
1.96\end{array}$ \\
\hline & $\begin{array}{ll}\text { RET } & 1 \\
\text { RET } & 2 \\
\text { RET } & 3 \\
\text { RET } & 4 \\
\text { RET } & 5 \\
\text { RET } & 6 \\
\text { RET } & 7 \\
\text { RET } & 8 \\
\text { RET } & 9\end{array}$ & $\begin{array}{l}= \\
= \\
= \\
= \\
= \\
= \\
= \\
= \\
=\end{array}$ & $\begin{array}{l}1.67 \\
2.19 \\
3.24 \\
1.82 \\
1.52 \\
1.24 \\
1.57 \\
1.75 \\
2.57\end{array}$ & & & & & \\
\hline \multirow[t]{2}{*}{$\begin{array}{c}\text { DATE } \\
3 / 27 / 83\end{array}$} & $\begin{array}{l}\text { HOUR } \\
22\end{array}$ & W & $\begin{array}{l}\text { SPEED } \\
2.0\end{array}$ & $\begin{array}{l}\text { WDIR } \\
270.0\end{array}$ & $\begin{array}{r}\text { T-OUT } \\
19.8\end{array}$ & $\begin{array}{l}T-I N \\
19.9\end{array}$ & $\begin{array}{c}T-D I F F \\
.1\end{array}$ & $\begin{array}{l}\text { AER } \\
1.09\end{array}$ \\
\hline & $\begin{array}{ll}\text { RET } & 1 \\
\text { RET } & 2 \\
\text { RET } & 3 \\
\text { RET } & 4 \\
\text { RET } & 5 \\
\text { RET } & 6 \\
\text { RET } & 7 \\
\text { RET } & 8 \\
\text { RET } & 9\end{array}$ & $\begin{array}{l}= \\
= \\
= \\
= \\
= \\
= \\
= \\
= \\
=\end{array}$ & $\begin{array}{r}1.91 \\
2.08 \\
2.16 \\
.68 \\
0.00 \\
.90 \\
0.00 \\
.91 \\
1.25\end{array}$ & & & & & \\
\hline \multirow[t]{2}{*}{$\begin{array}{c}\text { DATE } \\
3 / 28 / 83\end{array}$} & $\begin{array}{c}\mathrm{HOUR} \\
2\end{array}$ & W & $\begin{array}{l}\text { SPEED } \\
1.4\end{array}$ & $\begin{array}{l}\text { W DIR } \\
292.5\end{array}$ & $\begin{array}{r}T \text { - OU T } \\
19.5\end{array}$ & $\begin{array}{l}T-I N \\
19.7\end{array}$ & $\begin{array}{c}T-D I F F \\
.2\end{array}$ & $\begin{array}{l}\text { AER } \\
1.55\end{array}$ \\
\hline & $\begin{array}{ll}\text { RET } & 1 \\
\text { RET } & 2 \\
\text { RET } & 3 \\
\text { RET } & 4 \\
\text { RET } & 5 \\
\text { RET } & 6 \\
\text { RET } & 7 \\
\text { RET } & 8 \\
\text { RET } & 9\end{array}$ & $\begin{array}{l}= \\
= \\
= \\
= \\
= \\
= \\
= \\
= \\
=\end{array}$ & $\begin{array}{r}2.44 \\
2.24 \\
1.75 \\
2.04 \\
.92 \\
.69 \\
.63 \\
1.03 \\
3.01\end{array}$ & & & & & \\
\hline
\end{tabular}


TABLE 4. Air Exchange Rates with Building Pressurized to 8-14 Pa

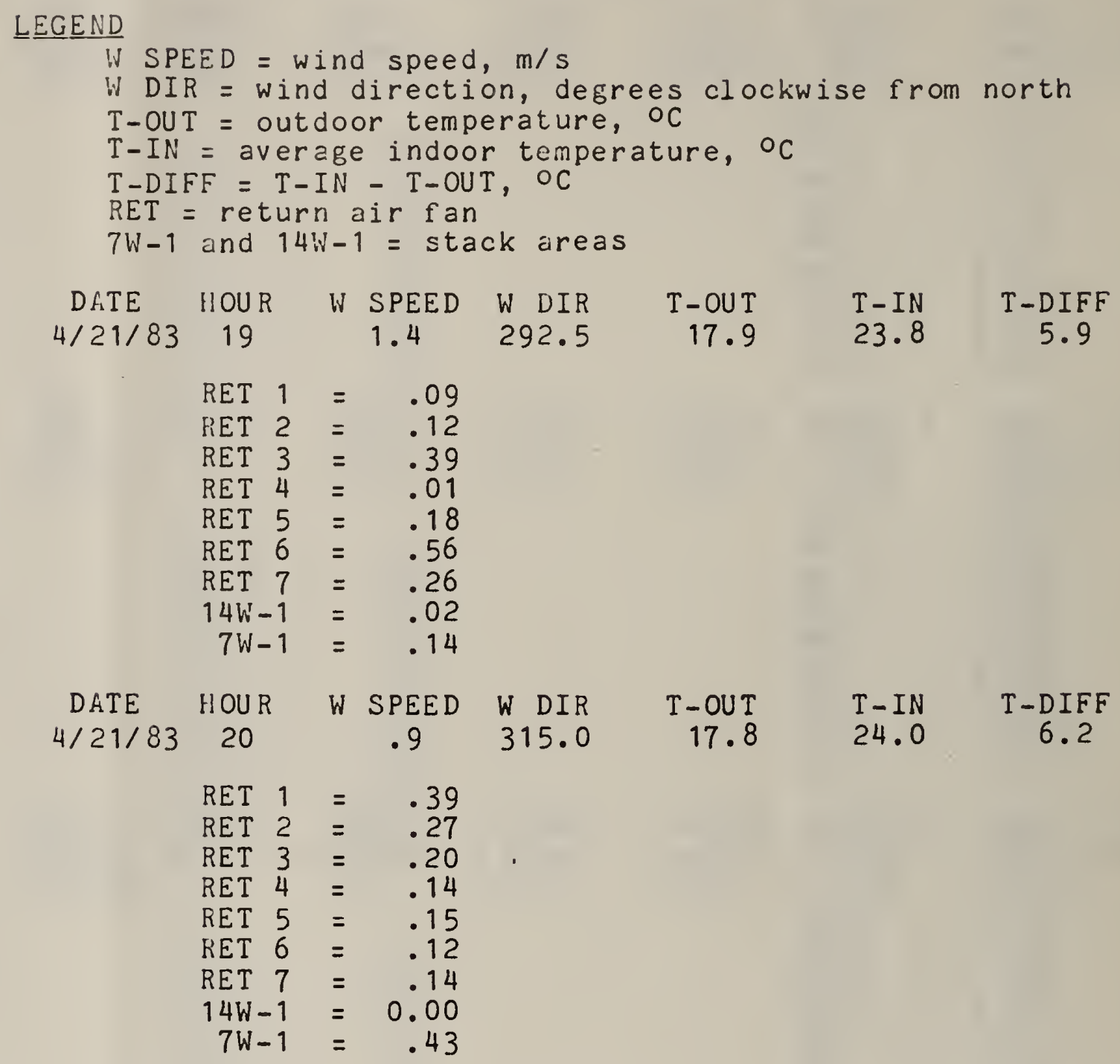




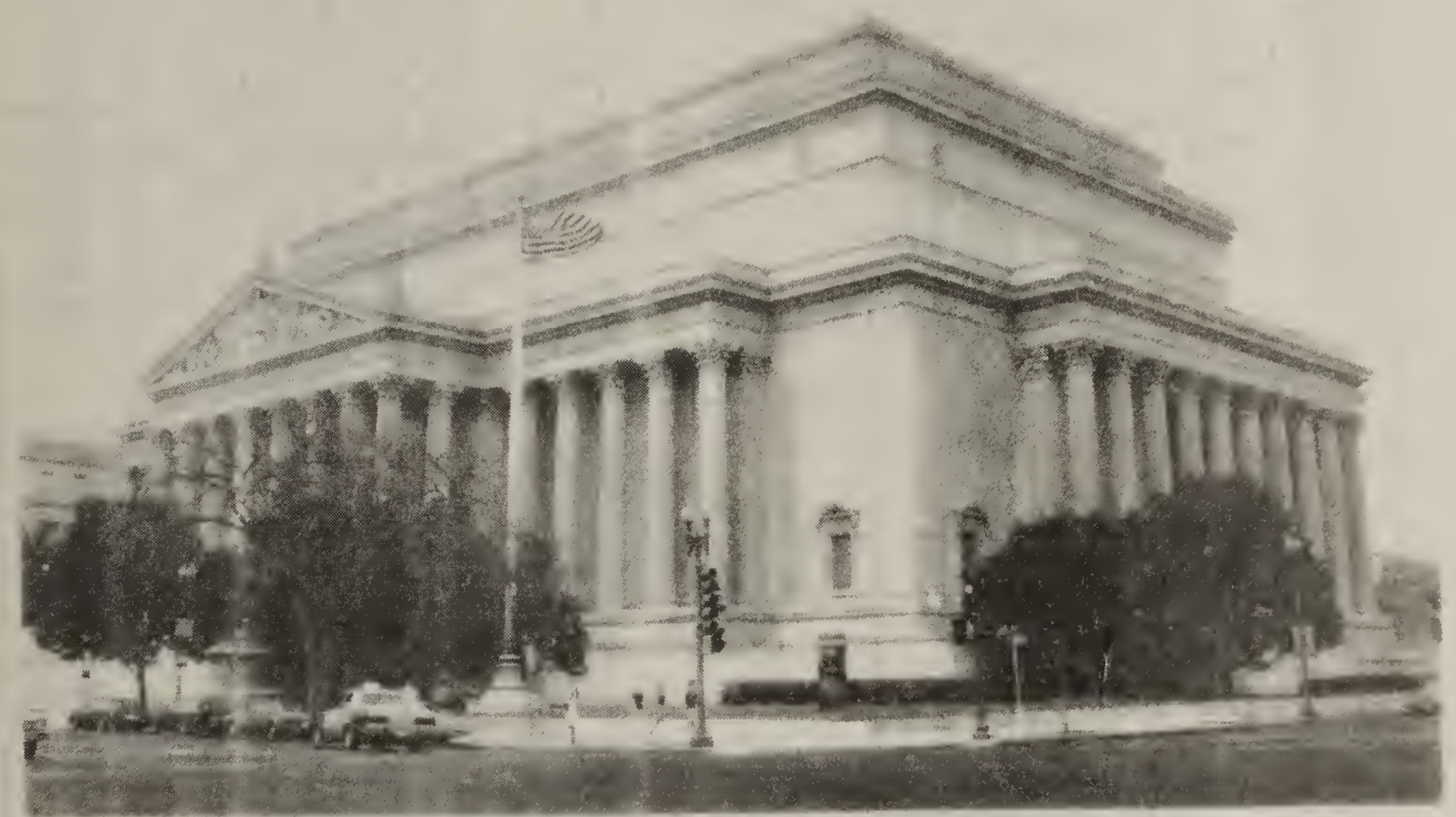

Figure 1. The National Archives Building, located between Pennsylvania and Constitution Avenues, and between 7 th and 9 th Streets, in downtown Washinglon. 


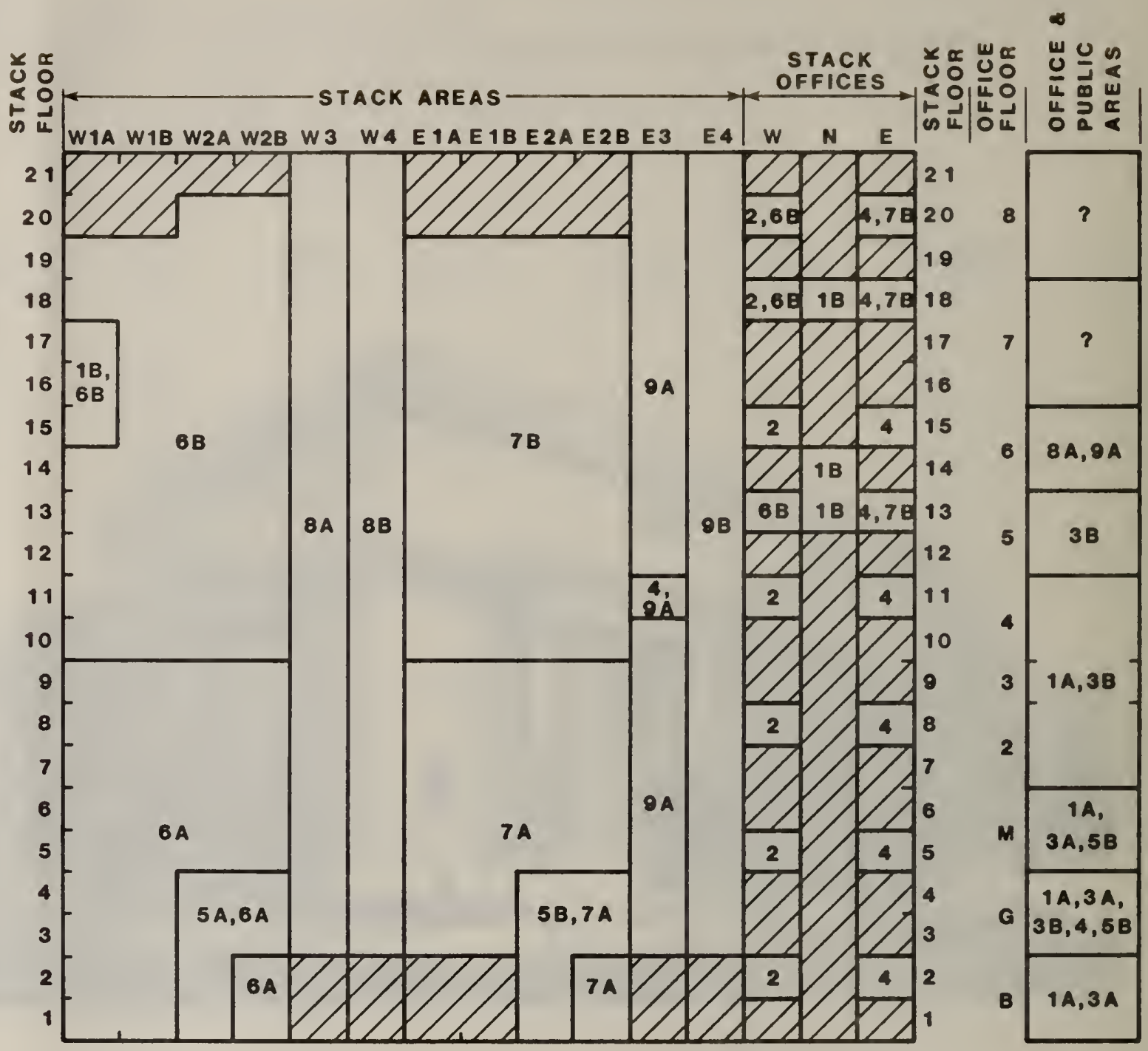

Figure 2. Schematic side view of National Archives Building, showing areas served by air-handling systems, from information supplied by GSA. Each of the nine air-handling systems of the building except 2 and 4 has two supply air fans labelled "A" and "B", and one return air fan; systems 2 and 4 have one supply and return fan each. All fans in each sy stem operate simultaneously. The numbers in the figure above refer to supply fans. 


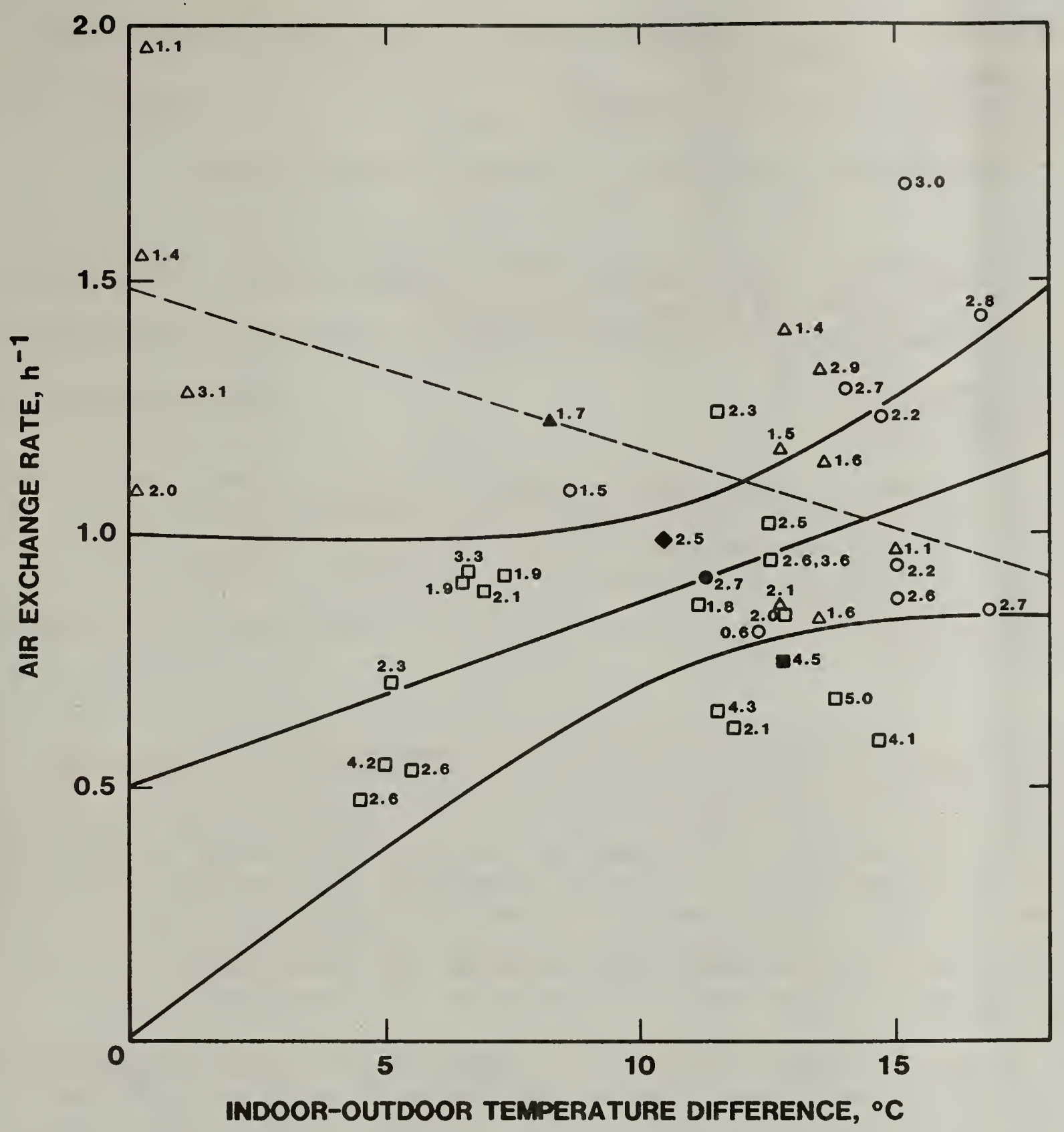

Figure 3. Relationship of air exchange rate to indoor-outdoor temperature difference and wind speed under normal fan operation and with outdoor air dampers closed. Wind speeds $(\mathrm{m} / \mathrm{s})$ are shown to the right of data points. Solid line is best-fit regression line for normal HVAC-system operation. Curves represent 1 standard error unit on each side of regression line. Dotted line is best fit regression line for outdoor air dampers closed. 0 , normal operation, early tests (see Methods); $\square$, normal operation, late tests (see Methods); $\boldsymbol{m}$, normal operation (late test), test of air mixing between stack areas and other areas; $\Delta$, outdoor air dampers closed; $\bullet$ normal operation average; $\Delta$, outdoor air dampers closed average; $\bullet$, overall average. 
NBS-114A (REV. 2-8C)

\begin{tabular}{|c|c|c|c|}
\hline $\begin{array}{c}\text { U.S. DEPT. OF COMM. } \\
\text { BIBLIOGRAPHIC DATA } \\
\text { SHEET (See instructions) }\end{array}$ & $\begin{array}{l}\text { 1. PUBLICATION OR } \\
\text { REPORT NO. }\end{array}$ & 2. Performing Organ. Report No. & 3. Publication Date \\
\hline 4. TITLE AND SUBTITLE & S $3-2770$ (GSA) & & September 1983 \\
\hline
\end{tabular}

Air Exchange Rate Measurements in the National Archives Building

5. AUTHOR(S) Samuel Silberstein, Richard A. Grot, Douglas O. Pruitt, Philip Engers, Patrick Lane and Steven E. Schweinfurth

6. PERFORMING ORGANIZATION (If joint or other than NBS. see instructions)

7. ContracUGrant No.

NATIONAL BUREAU OF STANDARDS

DEPARTMENT OF COMMERCE

WASHINGTON, D.C. 20234

9. SPONSORING ORGANIZATION NAME AND COMPLETE ADDRESS (Street, City, State, ZIP)

Public Building Service of the General Services Administration

7 th and D Streets, SW Washington, DC 20407 AND

National Archives and Record Service, National Archives Building,

Washington, DC 20408

10. SUPPLEMENTARY NOTES

Document describes a computer program; SF-185, FIPS Software Summary, is attached.

11. ABSTRACT (A 200-word or less factual summary of most significant information. If document includes a significant bibliography or literature survey. mention it here)

Air exchange measurements were carried out at the National Archives Building under various combinations of temperature and wind speed. The average air exchange rate under normal operation of the heating, ventilating, and air-conditioning system (HVAC) was $0.9 \mathrm{~h}^{-1}$ for an average temperature difference of $11.3^{\circ} \mathrm{C}$ and an average wind speed of $2.7 \mathrm{~m} / \mathrm{s}$. This rate is approximately twice those for new General Services Administration (GSA) office buildings. No clear dependence of air exchange rate on temperature differences up to $17^{\circ} \mathrm{C}$ or wind speeds up to $5 \mathrm{~m} / \mathrm{s}$ was found.

With outdoor air dampers closed and fans operating, the average air exchange rate was $1.2 \mathrm{~h}^{-1}$ for an average temperature difference of $8.2^{\circ} \mathrm{C}$ and an average wind speed of $2.8 \mathrm{~m} / \mathrm{s}$.

A test of interzone air movement showed that air migrates rapidly from non-stack to stack areas with fans operating normally.

The building could not be pressurized beyond an indoor-outdoor pressure difference of $14 \mathrm{~Pa}$. At this pressure difference, the air exchange rate was $1.5 \mathrm{~h}^{-1}$. As in the case of normal operation of the HVAC system, this rate is also approximately twice those for new GSA office buildings.

12. KEY WORDS (Six to twelve entries; alphabetical order; capitallze only proper names; and separate key words by semicolons) Air exchange rate; archives; building envelopel infiltration; pressurization; records storage; ventilation.

\section{AVAILABILITY}

Xx] Unlimited

For Official Distribution. Do Not Release to NTIS

Order From Superintendent of Documents, U.S. Government Printing Office, Washington, D.C. 20402.

XX] Order From National Technical Information Service (NTIS), Springfield, VA. 2216I

14. NO. OF

PRINTED PAGES

26

15. Price

$\$ 8.50$ 

